\title{
Comparison of Discovery and Inquiry Model: Which Model is More Effective in Natural Science (IPA) Learning?
}

\author{
Dyah Galih Rizki WULANDARI ${ }^{1}$, Ali MUSTADI ${ }^{2}$
}

\begin{tabular}{l} 
ARTICLE INFO \\
\hline Article History: \\
Received \\
20.04.2019 \\
Received in revised \\
form 06.09.2019 \\
Accepted \\
Available online \\
01.11.2019
\end{tabular}

\begin{abstract}
The purpose of this study is to find out the effectiveness of discovery learning and enquiry learning model toward learning outcome in natural science (IPA) subject especially in chapter of plant and its part. This study was conducted on 162 students of 4th grade of elementary school in Kendali Sodo. This is an experimental study with nonequivalent posttest design. Meanwhile the sampling cluster sampling model which use $3 \mathrm{SD}$. Data analysis result using N-gain score show that mean of experiment class discovery (ecd) was 78,1057, experiment class inquiry (eci) was 76,6121 and control class was 41,7720. Meanwhile the T-test show that experiment class discovery has $\mathrm{t}$ value as $6,639>$ from $\mathrm{T}$ table $(1,679)$, and T-value enquiry class as $t 6,506>$ from $\mathrm{T}$ table (1678). Therefore it can be concluded that the discovery and inquiry models have a significant effect on student learning outcomes. The result also show that the discovery model was the model that had the most significant effect compared to the inquiry model on student learning outcomes in the natural science lesson, especially plant material and its parts.
\end{abstract}

\section{Keywords:}

(C) IJERE. All rights reserved

Discovery learning, inquiry, natural science

\section{INTRODUCTION}

Entering $21^{\text {st }}$ century, preparing gold generation in facing globalization is an important thing to think of. One way to chose is by education, because the community has now become aware by increasing the quality of individuals in their groups (Duman \& Karagoz, 2016; Kaya, 2018) In more detail (Kemendiknas ,2013) stated that in achieving education goal, formal education is established systematically, structured and well directed. Formal educaton provide learning process which is expected to be able to raise and increase Higher Order Thinking Skill (HOTS). This idea is supported by the statement of (Irawati \& Mustadi, 2019) which stated that learning process in school is one of ways to improve HOTS. HOTS can be developed through several lessons in school, one of those is the lesson about plant and its part in natural science subject, in which the students are required to solve the problem through observation and make a conclusion. Supporting the previous statement (Harlen \& Quarter, 2018) stated that the basic thing in science is the involvement of students which started from finding the problem, identifiying problem, developing idea, discussion, solving the problem, and communicating it. All the series highly support the improvement of HOTS of students. This phenomenon is strengthened

Corresponding e-mail: dyahgalihrizkiwulandari.2017@student.uny.ac.id ${ }^{1}$; ali_mustadi@uny.ac.id ${ }^{2}$

Orcid Kode: orcid.org/0000-0001-9755-4568 ${ }^{1}$; orcid.org/0000-0002-7620-4582 ${ }^{2}$

Student Magister of Pendidikan Dasar, Univertitas Negery Yogyakarta ${ }^{1}$; Lecture of Pendidikan Dasar, Univertitas Negery Yogyakarta ${ }^{2}$ 
by the statement of (Fitzgerald \& Smith, 2016) which emphasize that science can build the generation which more scientific through students' meta cognition. In addition, high quality learning process needs teachers who know the method, strategy, approach up to model implemented (Barus \& Sani, 2017).

Many learning models are spread in school environment, but there are two models that are often used for primary schools, especially for the natural science lessons. Some studies show discovery are often used in natural science such as research of (Destalina et al, 2019) which emphasizes that discovery oriented inquiry towards student understanding. There is also another research study (Bahari et al, 2018) which shows that discovery has a good effect in natural science learning compared to conventional learning models. While inquiry models are also often found in science learning, one of which belongs to (Septya, 2018) which shows that learning with inquiry models can make students think critically. In line with previous research, (Adirahayu, 2018) which also used the inquiry model in his research which shows that the inquiry model has a better (more effective) effect in science learning on students' science process skills. Based on the above research it can be concluded that the models that are often encountered in natural science learning are the discovery and inquiry models, both of these models emphasize answering a problem through investigation. The inquiry model will begin by identifying which will produce assumptions, then it was communicated with logical and critical thinking so that they can find an alternative explanation of a problem (Anggraeni, et al 2018). This is supported by research of (Yohana et al, 2018) which stated that the process begins by allowing students to observe items that are around them. Then proceed with discussion, communicating, and drawing conclusions. This research shows that students' skill in conserving has increased to 84, general science skills increased to 73. Almost similar to the previous model, the discovery model emphasizes the ability to develop children's meta cognition based on experiment in order to gather the information they need (Ellizar et al, 2018). In conclusion, in general discovery is covered in inquiry. Discovery affect the learning of natural science, this is confirmed by research of (Ali \& Setiani, 2018) which shows that discovery learning affect student learning outcomes on the concept of mushrooms. Based on some of the above studies it can be concluded that the discovery and inquiry learning model can solve existing problems effectively.

The result of interviews with elementary school teachers in Kendalisodo, it shows that 2 out of 8 teachers had used the discovery model but had not used the inquiry model. 3 out of 8 teachers have used inquiry models but have not used discovery models. While the remaining 3 use other learning models. Thus there are no teachers who use both models altogether.

Based on the description above, researchers want to find out the differences in student learning outcomes using the discover model and inquiry model. Therefore the effectiveness of the two models on student learning outcomes in natural science lessons in elementary schools can be found out. Because basically discovery and inquiry have different syntax, the teachers can use this research as consideration material to determine the learning model that is more suitable with the material to be used.

\section{Aim of the Study}


The purpose of this study was to determine the effectiveness of the two models, the discovery and inquiry models of the learning outcomes of 4 th grade students in Kendali Sodo cluster.

\section{METHOD}

This study was in the form of an experiment with a quasi-experimental design. (Sugiyono, 2013) in this design had a control group/class, but does not fully function in controlling external variables that might affect the implementation of the experiment. It was also supported by Johnson \& Christensen's statement (2014: 485-486) which emphasizes that this experiment tends not to give full control over potential variables that can interfere with the experiment.

Therefore, in conducting research, researchers use existing classes, with the design of Nonequivalent Pretest- Posttest Control Group. This design refers to the use of 3 classes; those are the control class consisting of 1 class and the treatment class consisting of 2 classes (discovery class and class inquiry). Pretest and posttest are given to both control class and the treatment class; it was intended to determine the effectiveness of the learning model of student learning outcomes in natural science lessons.

\section{Material}

This study used a population of 4th Grade students from 8 elementary schools in Kaligesing Sub-district, Purworejo Regency, with 162 students consisting of 10-11 years old. The next researcher determines the research sample with cluster sampling technique on the basis that the population data was normally distributed and homogeneous. Thus the samples obtained were SD IV Sumowono as many as 24 students and SD IV Tlogobulu as many as 22 students as the experimental class, and SD IV Pandanrejo as many as 26 as the control class. In the experimental class SD Sumowono received treatment by applying the discovery learning model, while in the experimental class SD Tlogobulu received treatment by applying the inquiry model to plant material and its parts.

The independent variables in this study were discovery and inquiry learning model. The dependent variable in this study was the student learning outcomes in plant material and its parts. This research uses the instrument in the form of a test. This test instrument was in the form of a description question of 10 items that have been tested for reliability, validity, compensation, and the level of difficulty..

Data collection was carried out through pretest and posttest, the data that have been collected subsequently were analyzed descriptively and normality test and homogeneity test. The statistical methods used in this study were variety, mean, and standard deviation. The next step was the data that has been analyzed using homogeneity and normality tests will be found for the N-Gain Score. Furthermore the data will be processed using the T-test; this is intended to determine the effect of using discovery and inquiry learning models on learning outcomes. The final step was to compare the effect of discovery on science learning outcomes and the effect of inquiry on science learning outcomes. 


\section{FINDINGS}

The initial data collection was carried out by conducting the pre-test. Following the data about the pre-test of $4^{\text {th }}$ grade students in the experimental and control classes as shown on table 1.

Table 1. Pretest of experiment class discovery (ecd), experimental class inquiry (eci) and control class (cc)

\begin{tabular}{ccccc}
\hline No & Description & ECI & ECD & CC \\
\hline 1 & Number of sample & 24 & 22 & 26 \\
2 & Minimal Score & 0 & 0 & 0 \\
3 & Maximal Score & 80 & 100 & 80 \\
4 & Total & 910 & 1010 & 1010 \\
5 & Mean & 37.91666667 & 45.90909091 & 38.84615385 \\
6 & KKM & 70 & 70 & 70 \\
7 & Achieve KKM & 2 & 5 & 2 \\
8 & Do not achieve KKM & 22 & 17 & 24 \\
\hline
\end{tabular}

the data was used to assess the students' initial abilities before receiving treatment

Furthermore, the pretest data were analyzed using the normality test, to determine the distribution of data from the initial pretest data in 4 th grade in the ECD, ECI and CC classes which as shown on Table 2.

Table 2. Pretest normality test results of experiment class discovery (ecd), experimental class inquiry (eci) and control class (cc)

\begin{tabular}{lllccc}
\hline No & Class & N & K-S Z & Lt (real level 5 \%) & Note \\
\hline 1 & Enquiry Experiment & 24 & 0,787 & 0,05 & Normal \\
2 & Discovery Experiment & 22 & 0,547 & 0,05 & Normal \\
3 & Control & 26 & 0,703 & 0,05 & Normal \\
\hline
\end{tabular}

The homogeneity test on the pretest data is used to determine the diversity of data on the pretest presented on table 3 .

Table 3. Pretest of experiment class discovery (ecd), experimental class inquiry (eci) and control class (cc)

\begin{tabular}{ccccc}
\hline No & Description & Sig & Lt (real level & \multirow{2}{*}{ Note } \\
\hline 1 & ECl & 0,281 & 0,05 & Homogenous \\
2 & ECD & 0,077 & 0,05 & Homogenous \\
3 & CC & 0,427 & 0,05 & Homogenous \\
\hline
\end{tabular}

Based on the results of pretest data analysis, it can be concluded that students' cognitive abilities from both the experimental class and the control class were the same. This homogeneity aside from cognitive abilities, was also considered from the curriculum of the material and the student's environment. This is intended so that the data obtained are more accurate. 
After taking the initial data and analyzing it, the researcher continued the research by giving treatment to discovery and inquiry experimental classes. Treatment was given to lesson of plant and its parts in the of natural science lessons in 4th grade. the treatment of inquiry learning model. Furthermore, SDN Pandanrejo as a control class, and did not receive any treatment. The experimental class was treated 4 times, after the treatment was given the researcher took the data by conducting posttest. The data is shown on table 4 .

Table 4. Posttest of experiment class discovery (ecd), experimental class inquiry (eci) and control class (cc)

\begin{tabular}{ccccc}
\hline No & Description & ECI & ECD & CC \\
\hline 1 & Number of sample & 24 & 22 & 26 \\
2 & Minimal Score & 70 & 75 & 50 \\
3 & Maximal Score & 100 & 100 & 90 \\
4 & Total & 2010 & 1915 & 1710 \\
5 & Mean & 83.75 & 87.04545455 & 65.76923077 \\
6 & KKM & 70 & 70 & 70 \\
7 & Achieve KKM & 24 & 22 & 12 \\
8 & Do not achieve KKM & 0 & 0 & 14 \\
\hline
\end{tabular}

Based on the data in table 4 it can be assumed that student learning outcomes after getting treatment increases and all students have reached the minimum completeness criteria. Furthermore, the test data will be analyzed using the normality test and homogeneity test shown on table 4 .

Table 5. Normality test results of experiment class discovery (ecd), experimental class inquiry (eci) and control class (cc)

\begin{tabular}{lllccc}
\hline No & Class & N & K-S Z & Lt (real level 5\%) & Note \\
\hline 1 & Enquiry Experiment & 24 & 0,968 & 0,05 & Normal \\
2 & Discovery experiment & 22 & 0,889 & 0,05 & Normal \\
3 & Control & 26 & 1,185 & 0,05 & Normal \\
\hline
\end{tabular}

The homogeneity test on the pretest data was used to determine the diversity of data on the pretest presented in table 6.

Table 6. Postest of experiment class discovery (ecd), experimental class inquiry (eci) and control class (cc)

\begin{tabular}{ccccc}
\hline No & Description & Sig & Lt (real level 5\%) & Note \\
\hline 1 & ECI & 0,978 & 0,05 & Homogenous \\
2 & ECD & 0,603 & 0,05 & Homogenous \\
3 & CC & 0,484 & 0,05 & Homogenous \\
\hline
\end{tabular}

Table 6 shows that the data taken from the test were homogeneous. This can be seen from the significance level of ECI, ECD, and CC which are all more than 0.05.

Normality and homogeneity tests are prerequisite tests to test hypotheses in research. After knowing that the processed data is included in normal and homogeneous data, then the N-Gain Score is calculated as shown on Tables 7 and 8.

Table 7. Results of ECD calculation toward the CC Gaint Test 


\begin{tabular}{ccccc}
\hline Description & Mean & Max & Min & Note \\
\hline ECD & 78,1057 & 100 & 50 & Effective \\
CC & 41,7720 & 75 & 0 & Less effective \\
\hline
\end{tabular}

Table 8. Result of ECI calculation toward CC Gaint Test

\begin{tabular}{ccccc}
\hline Description & Mean & Max & Min & Note \\
\hline $\mathrm{ECl}$ & 76,6121 & 100 & 25 & Effective \\
$\mathrm{CC}$ & 41,7720 & 75 & 0 & Less effective \\
\hline
\end{tabular}

Table 7 shows that the average value of ECD was higher than the average value of CC (78.1057> 41.7720), so that ECD can be assumed to have high changes in student learning outcomes. While table 8 shows that the mean score of ECI is also higher than the average score of CC (76.6121> 41.7720), so it can be assumed that ECI had a higher change than CC in student learning outcomes. Furthermore, to find out the effectiveness of the discovery and inquiry models a t-test was shown on table 9.

Table 9. T-test result of ECD, ECI

\begin{tabular}{lccc}
\hline Description & t-value & T-table & Note \\
\hline $\mathrm{ECD}$ & 6,639 & 1,679 & Effective \\
$\mathrm{ECl}$ & 6,506 & 1,678 & Effective \\
\hline
\end{tabular}

Table 9 shows that the statistical value of $t$ from the results of $t$ test for ECD is 6.639 which is greater than $T$ table $(6.639>1.679)$, while for ECI which is 6.506 is greater than $T$ table (6.506>1.678). Thus it can be assumed that the discovery and inquiry learning model is effective toeard student learning outcomes in plant material and its parts.

\section{RESULT, DISCUSSION, AND SUGGESTIONS}

This research is relevant to research of(Isnardiantini et al, 2018) which shows the results that learning mathematics based on discoveri learning is able to improve student learning outcomes. This is indicated by statistical data 2,490> from T-table $(1,997)$. Not significantly different from previous research, the research (Sari et al, 2018) stated that inquiry-based science teaching materials are very well applied in science learning, this is supported by an N-Gain score of 70.47 with high criteria.

The high effectiveness of discovery learning models for student learning outcomes in this study is possible because of the learning syntax that is able to make students able to construct their own knowledge through discovery. This is supported by research of (Rahayu \& Putriani, 2018) which states that in his research students are more flexible to express answers with findings and build on their knowledge and transfer their knowledge. In line with the discovery model, the inquiry model also provides high effectiveness on learning outcomes, it can be assumed because the inquiry model directs students to be able to think critically and respond to problems to be solved. Supporting the previous statement (Rangkuti \& Sani, 2018) which stated that the main concept of inquiry 
is critical and analytical thinking which can encourage students to think at a high level (HOTS) so that students can solve their problems correctly.

Cosidered from data analysis, it stated that the learning model of discoveri and inquiry was effective toward student learning outcomes in lessons of plant and its parts. However, the mean N-Gain Score of the two models is not the same. The discovery model has a mean of 78.1057, while the inquiry model has a mean of 76.6121. Based on these data it can be concluded that the mean discovery model is higher than the mean of inquiry model. The mean difference between the two models is 1.4936, the difference is indeed very small. Thus it can be concluded that the discovery model has a higher effect than the inquiry model on student learning outcomes in lessons of plant and its parts.

Researchers suggest the use of discoveri models to be prioritized over other models for learning Natural Sciences, especially in lessons of plant and its parts. Considered from the importance of the learning process to achieve goals, the teacher as a facilitator should be able to design and facilitate students to solve the problems.

\section{REFERENCES}

Adirahayu, M., F. (2018). Pengaruh model pembelajaran inkuırı terbimbing terhadap keterampilan proses sains siswa kelas VIII di SMP Negerı 2 Wonoayu. Undergraduate thesis, Universitas Muhammadiyah Sidoarjo.

Ali, M., \& Setiani, D., S., (2018). Pengaruh model discoveri learning terhadap hasil belajar peserta didik pada konsep jamur. Bioedusiana 3 (2).

Anggraeni, P., Sopandi W., \& Widodo A. (2018). Profil pertanyaan inkuiri guru pada pembelajaran ipa di sekolah dasar. Mimbar Sekolah Dasar, 5 (2).

Bahari, N., K., I., Darsana, I., W., Putra, D., K., N., S. (2018). Pengaruh model discovery learning berbantuan media lingkungan alam sekitar terhadap hasil belajar ipa. Jurnal Ilmiah Sekolah Dasar (PGSD), 2 (2).

Barus, E.L. \& Sani, R.A. (2017). Pengaruh model pembelajaran latıhan inkuirı terhadap hasıl belajar siswa pada materı pokok usaha dan energı di kelas $X$ semester II. Jurnal Inovasi Pembelajaran Fisika (INPAFI) 5 (4).

Destalina, Ali, M., S., \& Palloan, P. (2019). The effectıvity of discovery learning application in inquiryoriented science learning towards understanding the concept of physics of students in grade XI IPA SMAN 13 Makassar. Jurnal Sains dan Pendidikan Fisika (JSPF), 15(1), 1-7.

Duman,T. \& Karagoz,S. (2016). An evaluation of Turkish teacher education system compared to other models in different countries.International Journal of Educational Research Review , 1 (1), 1-13.

Ellizar, E., Hardeli, H., Beltris, S., \& Suharni, R. (2018). Development of scientific approach based on discoveri learning module. IOP Conf. Series: Materials Science and Engineering. 
Fitzgerald, A., \& Smith, K. (2016). Science that matters: exploring science learning and teaching in primary schools. Australian journal of teacher education, 41(4). http://dx.doi.org/10.14221/ajte.2016v41n4.4.

Harlen, W. \& Qualter, A. (2018). The teaching of science in primary schools. London: David Fulton Pubhliser

Irawati,E. \& Mustadi,A. (2019). Learning together assisted with of 7-in-1 box: Creating effectiveness of mathematic learning outcomes of elementary school. International Journal of Educational Research Review,4 (3), 310-319.

Isnardiantini,S., Usodo,B. \& Soegiyanto,H. (2019). The effect of discoveri learning - based teaching material by utilizing traditional game on mathematic abilities of the 2nd graders of elementary school. International Journal of Educational Research Review,4(3),269 -274.

Kaya, İ.(2018).Examination of preschool teachers' opinion on alternative assessment. Universal Journal of Educational Research, 6(10), 2294-2299

Kementerian pendidikan dan kebudayaan (2013). Kurikulum 2013 Kompetensi Dasar SD/ MI

Rahayu, C., \& Putriani, D., (2018). The effect of discoveri learning model using sunflowers in circles on mathematics learning outcomes. International Journal of Trends in Mathematics Education Research 1(1)

Rangkuti, M., A., \& Sani, R., A., (2018). Analisis kemampuan berfikir kritis menyelesaikan masalah fisika pada pembelajaran dengan model pembelajaran inkuiri. Jurnal Inovasi Pembelajaran Fisika (INPAFI) 6(3)

Sari, B., S., K., Jufri, W., A., \& Santosa, D., (2019). Pengembangan bahan ajar IPA berbasis inkuiri terbimbing untuk meningkatkan literasi sains. Jurnal Penelitian Pendidikan IPA, (JPPIPA), 5 (2) 2019: 219-227

Septya, A., (2018). Implementasi strategi pembelajaran inkuiri untuk meningkatkan hasil belajar IPA materi penjernihan air sederhana. Universitas Muhamadiyah Sidoarjo

Yohana, I., Sudarmin, S. Wardani, S. \& Mohyaddin, S. N. B. (2018). The generic science skill profile of fourth grade students on acid and base topic in guided inquiry learning model. International Journal of Active Learning, 3(2), 110-116. 